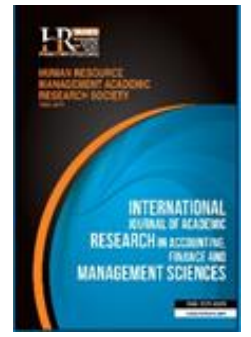

International Journal of Academic Research in Accounting, Finance and Management Sciences

Vol. 9, No.1, January 2019, pp. 1-10

E-ISSN: 2225-8329, P-ISSN: 2308-0337

(C) 2018 HRMARS

www.hrmars.com

To cite this article: Nyabira, B. O., Otiso, W. O.., Kaguta, J. (2019). Effect of Police Training Programme Content and Delivery Methods on Counter-Terrorism Capability in Kenya, International Journal of Academic Research in Accounting, Finance and Management Sciences 9 (1): 1-10.

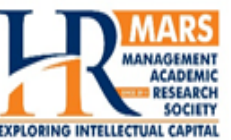

http://dx.doi.org/10.6007/IJARAFMS/v9-i1/5719 (DOI: 10.6007/IJARAFMS/v9-i1/5719)

\title{
Effect of Police Training Programme Content and Delivery Methods on Counter-Terrorism Capability in Kenya
}

\author{
Bobby Okari Nyabira ${ }^{1}$, Wycliffe Nyachoti Otiso ${ }^{2}$, Joyce Kaguta ${ }^{3}$ \\ ${ }^{1}$ Dedan Kimathi University, E-mail: bobbyokari@gmail.com \\ ${ }^{2}$ School of Law, Kisii University, E-mail: nyachoti@gmail.com \\ ${ }_{3}^{3}$ Institute of Criminology, Forensics and Security Studies, Dedan Kimathi University, E-mail: kagutajoy@gmail.com
}

\begin{abstract}
The main purpose of this study was to determine the effect of police training programme content and delivery methods on Counter-Terrorism Capability in Kenya. The study was grounded on conflict theory and Andragogy theory. The study adopted descriptive research design. The study targeted 582 officers comprising of Training Officers (TOS) and Chief Instructors (Cls) from the Administration Police Training College, Kiganjo police training college and the GSU training college in Embakasi. The study used proportionate random sampling. A sample size of 85 respondents was determined based on the work of Yamane. An interview guide and structured questionnaire was used to collect data. The study carried out a pilot test at Loresho Staff College to check for reliability and validity of the questionnaire. Regression analysis tests on multicollinearity and normality were carried out to determine whether the data are in line with the assumptions of OLS. Both multivariate and bivariate analyses were carried out using SPSS version 22. Descriptive and inferential analysis was carried out. Regression analysis findings indicated that training Programme content and Programme delivery methods have a positive and significant association with the police Counter-Terrorism Capability in Kenya. The study established that training Programme content with terror detection skills, prevention skills, response skills, terror-related investigative skills and paramilitary skills positively and significantly influences the police counter-terrorism capability in Kenya. The study recommends the administration of the Kenya Police Colleges to review and ensure that content of their training Programme equips the police with terror detection skills, to adopt the right training Programme design for training police officer sand to conduct joint trainings with other police formation in order to bridge the differences in terms of Programme for curbing terrorism with other countries.
\end{abstract}

Key words

Programme Content, Programme Delivery Methods, Counter-Terrorism Capability

Received: 03 Mar $2019 \quad$ (c) The Authors 2019

Revised: 16 Mar 2019 Published by Human Resource Management Academic Research Society (www.hrmars.com)

Accepted: 23 Mar 2019 This article is published under the Creative Commons Attribution (CC BY 4.0) license. Anyone may reproduce, distribute, translate and create derivative works of this article (for both commercial and Published Online: $25 \mathrm{Apr} 2019 \begin{aligned} & \text { reproduce, distribute, translate and create derivative works of this article (for both commercial and } \\ & \text { non-commercial purposes), subject to full attribution to the original publication and authors. The full } \\ & \text { terms of this license may be seen at: http://creativecommons.org/licences/by/4.0/legalcode }\end{aligned}$

\section{Introduction}

To a police officer the need for solid, regular and relevant trainings is vitally critical for purpose of achieving relevant Capability given the nature of policing. As early as 1930 s, pioneer scholarly work had already recognized the importance of improving the police Capability to efficiently handle day to day tasks, (Renden et al., 2015). A police officer on duty must promptly respond at a short moment's notice, to any arising situation, without expecting any immediate assistance, while taking cognizance of possible detrimental implications of decisions so made. The risks involved in police work demands the need for appropriately tailored training Programme to assist in achieving the relevant police Capability. Under such 
circumstances, Udrea (2014) describes training Programmes that are exclusively focused on what needs to be known and purposed to develop skills, modify behaviors and enhance competence. Baker (2011) indicate the importance of focused training, however, in the absence of it, it would take an officer a lifetime or more to learn through experience, all that pertains to police work.

According to Mbuba (2017) the common forms of police training Programme intended to equip officers with a wide range of policing related skills includes: initial training offered to new police recruits, inservice trainings for working officers and special trainings often offered on needs basis. The courses offered ranges from physical drills to Information and Communication Technology. However little is known in terms of empirical evidence on the effectiveness of these programmes in contributing to police Capability to handle emerging crimes and security issues.

The rise in Terrorism attacks increases the pressure on police to enhance their Counter-Terrorism Capability. This due to the fact that police in most countries are the agencies charged with chief responsibility for upholding the security of the public, (International Association of Chiefs of Police, 2005). However, Sandler (2015) indicated that police officers in most Terrorism-vulnerable countries often have poor skills and competencies for responding to terror threats and attacks. Among the common aspects that affect the response efforts of police to Terrorism is intelligence gathering and analysis of information collected.

Police ought to rely on relevant training Programme designed to fill such skills and competencies gaps arising from changing work demands (Mogire and Mkutu, 2011). Unfortunately, most police organizations have been found to fail in planning and analyzing for their training needs. This has led to police training Programme that are ineffective in equipping the officers with the desirable skills and competencies as demanded by the new police work environment. Apart from countries that have frequently encountered Terrorism over the years (such as Pakistan, Syria and Afghanistan) and USA, the rest of the world uses either one of two intense methods of training police, (Global Terrorism Index, 2016).

According to Abraham and Collins (2011), needs assessment can be done through the explanation sequence of five phases to design a training and development syllabus for instance the needs appraisal, instructional objectives, design, execution/implementation and evaluation. The needs assessment helps in the determination of performance necessities or requirements in institutions so as to help channel capital to the specific areas that require more resources, those that are directly linked to achieving the institutional aims and objectives, increasing the efficiency and providing valuable and high standard outcomes.

In Kenya more than 440 terrorist attacks have been reported between 1970 and 2014 leaving more than 1,400 people dead and more than 5800 others wounded (Cronin 2016). Like in many other countries Police are actively involved in Counter-Terrorism. A formal appraisal report by GoK and UNDP (2015) indicated that police faced challenges in their investigative role of terror-related cases, leading to failed prosecution of terror suspect and low conviction rates. Specifically, the investigating agencies have in numerous court trials of terror suspects displayed a disturbingly high level of incompetence in converting intelligence into effective admissible evidence for a successful prosecution. Such failure not only emboldens terror perpetrators but undermines other Counter-Terrorism initiatives critically disabling the country's Counter-Terrorism Capability.

\section{Literature review}

\subsection{Police Training and Counter- Terrorism}

Police training refers to the imparting of new recruits and existing police officers with the relevant skills such as investigative and incident response skills. This study reviewed literature so as to comprehend the effect of police training programmes in stemming Terrorism. The review of existing and relevant literature on the effect of police training programmes on counter-Terrorism Capability in Kenya has revealed several research gaps that the current study attempted to address. A study such as by Pelfrey (2010) ascertained that police agencies have carried out scenario training before and revealed that 37 percent of the agencies had participated in that type of training. The study presented a conceptual gap as it only focused on training. Ojha and Puthali (2013) assessed training that demands for the development of the technical knowledge and skills essential for fresher and acquaintances serving in Nigeria. The study presented a contextual knowledge gap as it was carried out in Nigeria. Similarly, Mbuba (2017) looked at 
the courses offered at Police College revealed that some of the courses provided include traffic Capability, community policing, and public relation criminal procedure, criminal law and muster try. The study focused on police training college. This study assessed the effect of training programme on police CounterTerrorism Capability in Kenya.

\subsection{Training Programme Content and Counter-Terrorism Capability}

Wolf (2013) sought to look at the effectiveness of police training Programme at Pennsylvania municipal police colleges. The target population for the study was 152 municipal police officers. The results of the study showed that police receive the most sufficient instruction in form of awareness, skills, and character with regard to criminal law. The curricular focus of police was seen as the least efficient training quarter. However, the study highlighted training weaknesses especially on officer training which are insufficient with regard with Counter-Terrorism and cybercrime. Obisi, (2011) on staff training and improvement in Nigerian institutions established that with no training, it was difficult for employees to acquire needed skills, without which the organizations were not able to achieve their objectives. The study also found out that some organizations perceive training as unnecessary cost and thus opting for informally training sessions that are not based on specific organization's needs. Sedevic (2012) examined the activities and teaching carried out in police colleges in USA. The findings of the study showed that graduates from the Oakland Police College asserted that they were not adequately ready for about $34 \%$ of work duties they later had to carry out. This was attributed to irrelevant content of the academies trainings. Insufficient training of police trainees lays down new officer recruits up to certainly make errors.

\subsection{Training Programme Delivery Methods and Counter-Terrorism Capability}

Pelfrey (2010) carried out a study to determine the training methods used by New York Police Department (NYPD) concerning their instruction and if they have carried out scenario teaching previously. The findings of the study indicated that 37 percent of the NYPD agencies had taken part in scenario exercise. The study concluded that NYPD were not the only police agencies that carried out scenario teaching. The study established that NYPD had put in place an education curriculum for their detectives that comprised of one day of strategic role-playing set-ups. Chappell (2008) carried out a study to find out whether curriculum influenced the performance of recruits during the elementary police training under two diverse models of the core curriculum in Florida. The main aim of the study was to determine effectiveness of the Florida police training academies curricula with regard to police recruit focus during normal policing or community-based policing and whether the nature of the curriculum used for training influences recruits' academy performance. The findings of the study revealed that the police recruits trained using community-based policing Programmes performed well than those trained using the normal curriculum/Programmes. Further, Chappell and Lanza-Kaduce (2010) indicated that the training of the police recruits at the police training college that had recently initiated a community-based policing Programmes for instruction. The findings showed that the training learned in technical a paramilitary academy's' setting were robustly entrenched in the recruits in spite of the philosophical stress of the curriculum employed in teaching. The study concluded that these findings could be as a result of not just the settings of the instruction and the concentration into police sub-culture but also to the training methods used during teaching.

\section{Research Problem}

The concern of police preparedness in the wake of rising terrorist attacks in Kenya has come to the forefront since the kidnapping of tourists in Mombasa. Several terrorist attacks have since taken place in side Kenya including at the capital city of Nairobi. These attacks have resulted in several casualties and loss of property. The Westgate attack left at least 67 people dead while the Garissa University attack left at least 147 innocent lives dead and most recently the Dusitd2 attack on Riverside Drive in Westlands which left 21 people dead. These attacks have put more pressure on the Counter-Terrorism police as well other police agencies in Kenya with regard to first response to terrorist incidences and collection of Terrorism-related intelligence. Indication of skills and competency gaps in police Counter-Terrorism Capability has been evident during response to terror attack such as West gate and Garissa University attacks. The responses 
have been uncoordinated and characterized by poor communication and at times have resulted in fatal friendly fire. While Mbuba (2014) observed that police training curricular involves community policing, intelligence gathering and forensic investigations, the recent spate of terrorist activities carried out by Alshaabab elements in Kenya has called for a review in the police training curriculum to equip police and other security agencies in Kenya with effective Counter-Terrorism Capability. In Kenya, there is few documented empirical literature regarding the nature of existing police training Programme in Kenya and their impact on police Counter-Terrorism Capability. Therefore, carrying out this study is timely in bridging the existing literature gap. The study sought to assess the effect of police training programmes on counterTerrorism capacities.

\section{Methodology of research}

The study targeted the police training colleges which are Administration Police Training College in Embakasi, Kiganjo Police Training College and the General Service Training School Unit in Embakasi. A total of 582 officers consisting of 73 Chief Instructors (Cls) and 509 Training Officers (COs) were targeted. Proportionate random sampling was used to ensure that representatives from each sub-group are represented in the sample. A sample size 85 respondents was surveyed. The study used semi-structured questionnaires to collect primary data. The study used key informant interviews with open-ended questions so as to draw out more specific information as regards to police training Programme and how it affects the police Counter-Terrorism Capability in Kenya. Out of the 85 questionnaires administered to chief instructors and the training officers in the police training colleges in Kiganjo in Nyeri, APTC and the General Service Training School Unit in Embakasi, a total of 71 questionnaires were properly filled and returned representing $83.5 \%$ response rate.

\section{Results}

\subsection{Programme Content and Counter-Terrorism Capability}

The study sought to determine the effect of the police training programme's content on CounterTerrorism Capability in Kenya. The findings revealed that majority of the respondents agreed that Police training Programme equips them with terror detection skills as shown by a Mean of 4.49. Moreover, the findings of the study indicated that majority of the respondents strongly with the statements that Police are equipped with terror prevention skills (Mean=4.93). However, the findings of the study showed that majority of the respondents neither agreed nor disagreed with the statements that Police training Programme equips them with terror response skills and that Police training Programme contains terrorrelated investigative skills (mean $=3.39 \& 3.24$ respectively). Further, the findings of the study revealed that majority of the respondents agreed with the statement that police Counter-Terrorism Programme has paramilitary skills (Mean=3.59). On average, the findings of the study revealed that majority of the respondents agreed with the statements regarding training Programme content as indicated by a mean of 3.93. The findings also showed that responses given by the respondents were less varied as indicated by a standard deviation value of 0.97 .

Table 1. Descriptive Analysis for Programme Content

\begin{tabular}{lccccccc}
\hline \multicolumn{1}{c}{ Statements } & SD & D & N & A & SA & Mean & Std Dev \\
\hline $\begin{array}{l}\text { Police training Programme equips them with } \\
\text { terror detection skills }\end{array}$ & $0.0 \%$ & $2.8 \%$ & $21.1 \%$ & $0.0 \%$ & $76.1 \%$ & 4.49 & 0.92 \\
$\begin{array}{l}\text { Police are equipped with terror prevention } \\
\text { skills }\end{array}$ & $0.0 \%$ & $0.0 \%$ & $2.8 \%$ & $1.4 \%$ & $95.8 \%$ & 4.93 & 0.35 \\
$\begin{array}{l}\text { Police training Programme equips them with } \\
\text { terror response skills }\end{array}$ & $8.5 \%$ & $5.6 \%$ & $40.8 \%$ & $28.2 \%$ & $16.9 \%$ & 3.39 & 1.10 \\
$\begin{array}{l}\text { Police training Programme contains terror- } \\
\text { related investigative skills }\end{array}$ & $1.4 \%$ & $14 \%$ & $28.2 \%$ & $32.4 \%$ & $24 \%$ & 3.24 & 1.20 \\
$\begin{array}{l}\text { The police Counter-Terrorism Programme has } \\
\text { paramilitary skills }\end{array}$ & $1.2 \%$ & $5.6 \%$ & $25.4 \%$ & $28.2 \%$ & $39.6 \%$ & 3.59 & 1.28 \\
Average & & & & & & 3.93 & 0.97 \\
\hline
\end{tabular}

Where: $S D=S t r o n g l y ~ D i s a g r e e ; ~ D=D i s a g r e e ; ~ N=N e u t r a l ; A=A g r e e ; ~ S A=$ Strongly Agree 


\subsection{Influence of Programme Content on Counter-Terrorism Capability}

The bivariate linear regression model involving training Programme content and Counter-Terrorism Capability in Kenya is presented in table 2 below. The findings revealed that $R=0.402$ meaning that the linear regression model is positive, and $\mathrm{R} 2=0.161$ which means that Programme content accounts for $16.1 \%$ change in Counter-Terrorism Capability.

Table 2. Model Summary for Programme Content

\begin{tabular}{ccccc}
\hline Model & $\mathrm{R}$ & $\mathrm{R}$ Square & Adjusted R Square & Std. Error of the Estimate \\
\hline 1 & $.402 \mathrm{a}$ & 0.161 & 0.149 & 0.4459 \\
a Predictors: (Constant), Programme content & & & \\
\hline
\end{tabular}

The study used ANOVA to check whether the regression model is significant. The F-Critical, $F 0.05,1,69$

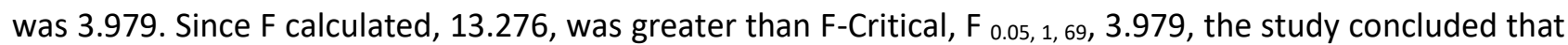
the model fit well. This is further supported by a p-value of 0.001 which is significant at $5 \%$ level of significance meaning that the model fit well.

Table 3. ANOVA Results for Programme Content

\begin{tabular}{ccccccc}
\hline Model & & Sum of Squares & Df & Mean Square & F & Sig. \\
\hline 1 & Regression & 2.639 & 1 & 2.639 & 13.276 & $.001 \mathrm{~b}$ \\
& Residual & 13.719 & 69 & 0.199 & & \\
& Total & 16.358 & 70 & & & \\
\hline
\end{tabular}

The regression coefficients for the model are presented in table 4. The regression results showed that Programme Content has a positive and significant influence on Counter-Terrorism Capability as indicated by a Beta coefficient of 0.311 and significance value of 0.001 .

Table 4. Regression Coefficients Results for Programme Content

\begin{tabular}{lccccc}
\hline & \multicolumn{2}{c}{ Unstandardized Coefficients } & \multicolumn{3}{c}{ Standardized Coefficients } \\
\cline { 2 - 5 } & $\mathrm{B}$ & Std. Error & Beta & $\mathrm{T}$ & Sig. \\
\hline (Constant) & 3.255 & 0.34 & & 9.572 & 0.000 \\
Programme content & 0.311 & 0.085 & 0.402 & 3.644 & 0.001 \\
\hline
\end{tabular}

\subsection{Interview Findings on the Effect of Police Training Programme-Content}

The findings of the informant interviews regarding whether police training Programme adequately equip police officers with Counter-Terrorism detection skills showed that police receive skills such as 'Handle Counter Terrorism Activities'. Moreover, the informants indicated that police recruits and those under specialized training receive 'Recognise Terrorist Threats training'. This enables the police to be able to spot or detect terrorist acts and other Terrorism related activities. According to the informants, police recruits are equipped with terror response skills such as judgement calls may require split decision making.

\subsection{Programme Delivery Methods and Counter-Terrorism Capability}

The study sought to determine the effect of the police training Programme delivery methods on Counter-Terrorism Capability in Kenya. The findings revealed that majority of the respondents agreed that the condition of the training environment affects police preparedness (Mean $=3.92$ ). The findings also revealed that the respondents agreed that Number of trainings affects police preparedness, (Mean $=4.32$ ). Moreover, the findings of the study indicated that the respondents agreed that Frequency of trainings affects police Counter-Terrorism Capability (Mean=3.61). Further, the findings of the study showed that majority of the respondents indicated that they agree that the length of trainings affects the level of police preparedness (mean=3.77). Lastly, the findings of the study showed that the respondents agreed that the level of the trainers' competence in Counter Terrorism affects the level of police preparedness (mean=3.92). On average, the findings showed that majority of the respondents agreed with the 
statements regarding the training Programme delivery methods (average mean=3.91). The responses given by the respondents were less varied as indicated by a standard deviation of 1.20.

Table 5. Descriptive Analysis for Programme Delivery Methods

\begin{tabular}{|c|c|c|c|c|c|c|c|}
\hline Statements & SD & D & $\mathbf{N}$ & A & SA & Mean & Std Dev \\
\hline $\begin{array}{l}\text { Training environment condition affects } \\
\text { police preparedness }\end{array}$ & $7.2 \%$ & $2.8 \%$ & $25.4 \%$ & $16.7 \%$ & $47.9 \%$ & 3.92 & 1.27 \\
\hline $\begin{array}{l}\text { Number of trainings affects police } \\
\text { preparedness }\end{array}$ & $2.8 \%$ & $7.0 \%$ & $5.6 \%$ & $23.9 \%$ & $60.7 \%$ & 4.32 & 1.05 \\
\hline $\begin{array}{l}\text { Frequency of trainings affects police } \\
\text { Counter-Terrorism Capability }\end{array}$ & $8.4 \%$ & $11.3 \%$ & $5.6 \%$ & $60.6 \%$ & $14.1 \%$ & 3.61 & 1.13 \\
\hline $\begin{array}{l}\text { Length of trainings affects the level of police } \\
\text { preparedness }\end{array}$ & $5.6 \%$ & $16.9 \%$ & $9.9 \%$ & $29.6 \%$ & $38.0 \%$ & 3.77 & 1.28 \\
\hline $\begin{array}{l}\text { The level of the trainers' competence in } \\
\text { Counter Terrorism affects the level of police } \\
\text { preparedness }\end{array}$ & $6.1 \%$ & $2.8 \%$ & $25.4 \%$ & $17.8 \%$ & $47.9 \%$ & 3.92 & 1.27 \\
\hline Average & & & & & & 3.91 & 1.20 \\
\hline
\end{tabular}

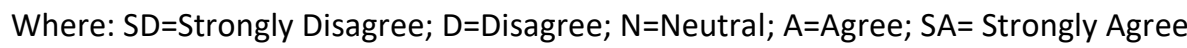

\subsection{Influence of Programme Delivery Methods and Counter-Terrorism Capability}

The bivariate linear regression model involving training Programme Delivery Methods and CounterTerrorism Capability in Kenya is presented in table 6 below. The findings revealed that $R=0.402$ meaning that the linear regression model is positive, and $R^{2}=0.177$ which means that Programme Delivery Methods accounts for $14.1 \%$ change in Counter-Terrorism Capability.

Table 6. Model Summary for Programme Delivery Methods

\begin{tabular}{ccccc}
\hline Model & $\mathbf{R}$ & R Square & Adjusted R Square & Std. Error of the Estimate \\
\hline 1 & $.420 a$ & 0.177 & 0.165 & 0.4418 \\
\hline
\end{tabular}

The study used ANOVA to check whether the regression model is significant. The F-Critical, $F_{0.05,1,69}$ was 3.979. Since $F$ calculated, 14.818, was greater than F-Critical, $F_{0.05,1,69}, 3.979$, the study concluded that the model fit well. This is further supported by a p-value of 0.000 which is significant at $5 \%$ level of significance meaning that the model fit well.

Table 7. ANOVA Results for Programme Delivery Methods

\begin{tabular}{ccccccc}
\hline Model & & Sum of Squares & Df & Mean Square & F & Sig. \\
\hline 1 & Regression & 2.892 & 1 & 2.892 & 14.818 & $.000 \mathrm{~b}$ \\
& Residual & 13.466 & 69 & 0.195 & & \\
& Total & 16.358 & 70 & & & \\
\hline
\end{tabular}

The regression coefficients for the model are presented in table 10. The regression results showed that Programme Delivery Methods has a positive and significant influence on Counter-Terrorism Capability as indicated by a Beta coefficient of 0.205 and significance value of 0.000 .

Table 8. Regression Coefficients Results for Programme Delivery Methods

\begin{tabular}{lccccc}
\hline & \multicolumn{2}{c}{ Unstandardized Coefficients } & \multicolumn{3}{c}{ Standardized Coefficients } \\
& B & Std. Error & Beta & T & Sig. \\
\hline (Constant) & 3.679 & 0.214 & & 17.16 & 0.000 \\
Programme delivery methods & 0.205 & 0.053 & 0.42 & 3.849 & 0.000 \\
\hline
\end{tabular}

\subsection{Interview Findings on the Effect of Programme Delivery Methods}

On whether the delivery methods [training techniques] employed in Police Colleges in Kenya is relevant, the informants indicated that the training techniques often employed are practical in nature. 
According to the informants, the most common method of training used is scenario-training where setting are normally simulated in order to prepare the trainees with the appropriate response during real combat.

\subsection{Descriptive Analysis for Counter-Terrorism Capability}

Respondents were asked to indicate the extent to which they agree or disagree with the statements on Police Counter-Terrorism Capability based on a 5-point Likert scale. The findings revealed that majority of the respondents strongly agreed that Police have the Capability to prevent Terrorism (Mean $=4.61$ ). The findings also revealed that the respondents strongly agreed that Police have the Capability to protect the citizens against terrorist acts, (Mean $=4.78$ ). Moreover, the findings of the study indicated that the respondents agreed that Police have the skills to detect and pursue Terrorism acts (Mean=3.79. Finally the findings of the study revealed that the respondents agreed that police have adequate skills to CounterTerrorism (mean=4.20). On average, the findings showed that majority of the respondents agreed with the statements regarding the training Programme administrative support (Average mean=4.40). The responses given by the respondents were less varied as indicated by a standard deviation of 1.02 .

Table 9. Counter Terrorism Capability

\begin{tabular}{|c|c|c|c|c|c|c|}
\hline Statements & SD & $\mathbf{N}$ & A & SA & Mean & Std Dev \\
\hline Police have the Capability to prevent Terrorism & $0.0 \%$ & $19.7 \%$ & $0.0 \%$ & $80.3 \%$ & 4.61 & 0.80 \\
\hline $\begin{array}{l}\text { Police have the Capability to protect the citizens } \\
\text { against terrorist acts }\end{array}$ & $0.0 \%$ & $0.0 \%$ & $11.3 \%$ & $88.7 \%$ & 4.78 & 0.00 \\
\hline $\begin{array}{l}\text { Police have the skills to detect and pursue Terrorism } \\
\text { acts }\end{array}$ & $\begin{array}{c}19.7 \\
\%\end{array}$ & $21.1 \%$ & $0.0 \%$ & $59.2 \%$ & 3.79 & 1.60 \\
\hline $\begin{array}{l}\text { The police have the adequate skills to Counter- } \\
\text { Terrorism }\end{array}$ & $0.0 \%$ & $0.0 \%$ & $80.3 \%$ & $19.7 \%$ & 4.20 & 0.40 \\
\hline Average & & & & & 4.40 & 1.02 \\
\hline
\end{tabular}

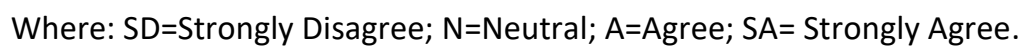

\subsection{Correlation Analysis}

The study carried out correlation tests to examine the association between Programme content, Programme design and Counter-Terrorism Capability. The findings are as shown in table 10 below.

Table 10. Correlation Results

\begin{tabular}{|c|c|c|c|c|}
\hline \multicolumn{2}{|c|}{ Correlations } & $\begin{array}{l}\text { Programme } \\
\text { design }\end{array}$ & $\begin{array}{l}\text { Programme delivery } \\
\text { methods }\end{array}$ & $\begin{array}{c}\text { Counter Terrorism } \\
\text { Capability }\end{array}$ \\
\hline Programme content & $\begin{array}{l}\text { Pearson Correlation } \\
\text { Sig. (2-tailed) }\end{array}$ & & & \\
\hline Programme delivery methods & $\begin{array}{l}\text { Pearson Correlation } \\
\text { Sig. (2-tailed) }\end{array}$ & $\begin{array}{l}0.114 \\
0.346\end{array}$ & 1 & \\
\hline Counter-Terrorism Capability & $\begin{array}{l}\text { Pearson Correlation } \\
\text { Sig. (2-tailed) } \\
\mathrm{N}\end{array}$ & $\begin{array}{c}.377^{*} \\
0.001 \\
71\end{array}$ & $\begin{array}{l}.449 * * \\
0.000 \\
71\end{array}$ & 71 \\
\hline
\end{tabular}

The correlation analysis findings indicated that training Programme content have a positive and significant association with the police Counter-Terrorism Capability $(r=0.377$, Sig $=0.001)$. This implies that the use of training Programme content that equips police with terror detection skills, prevention skills, response skills, terror-related investigative skills and paramilitary skills leads to a positive and significant effect in police Counter-Terrorism Capability in Kenya. The findings of the study are consistent those of Sedevic (2012) who showed that graduates from the Oakland Police College asserted that they were not adequately ready for about $34 \%$ of work duties they later had to carry out.

The findings also indicated that training Programme delivery methods had a positive and significant association with police Counter-Terrorism Capability $(r=0.449$, Sig $=0.000)$. This implies that training Programme delivery methods such as the condition of the training environment, number of trainings, the frequency of trainings, the length of trainings and the level of the trainers' competence positively and 
significantly influences police Counter-Terrorism Capability. The findings of the study are consistent those of McCay (2011) who indicated that whereas there is an inclination particularly for the State police colleges to equip police cadets using the military framework, police recruits can be successfully skilled using other non-military forms of training.

\subsection{Analysis}

The regression analysis model enabled the study to test the objectives of the study. The multiple linear regression equation adopted by the study is of the form $Y=\alpha+\beta_{1} X_{1}+\beta_{2} X_{2}+e$ where; $Y=$ CounterTerrorism Capability; $X_{1}=$ Programme Content; $X_{2}=$ Programme Delivery Methods while e error term.

Table 11. Model Summary

\begin{tabular}{cccc}
\hline $\mathrm{R}$ & $\mathrm{R}$ Square & Adjusted R Square & Std. Error of the Estimate \\
\hline .797 & 0.635 & 0.613 & 0.4986 \\
\hline
\end{tabular}

The model summary findings in Table 11 revealed that $R$ was 0.797 which indicates that the association between independent variables and the dependent variable is positive. $R$ squared refers to the fraction of the variation in dependent variable (Counter-Terrorism Capability) that can be accounted for by the independent variables (Programme content, Programme delivery methods). The findings indicated that Programme content and Programme delivery methods jointly account for up to $63.5 \%$ of the variations in police Counter-Terrorism Capability. This means that other factors not studied in this study account for the remaining $36.5 \%$ of variation in Counter-Terrorism Capability. Therefore, further research should be carried out to determine these factors.

The study used 2 way ANOVA to test if the model is good (fit) in determining the influence of Programme content and Programme delivery methods on Counter Terrorism Capability. The findings of the study are as indicated in Table 12 below.

Table 12. Analysis of Variance (ANOVA)

\begin{tabular}{lccccc}
\hline & Sum of Squares & Df & Mean Square & F & Sig. \\
\hline Regression & 28.548 & 4 & 7.137 & 28.706 & .000 \\
Residual & 16.409 & 66 & 0.249 & & \\
Total & 44.958 & 70 & & & \\
\hline
\end{tabular}

The findings indicate that $\mathrm{F}$ statistic which indicates the overall significance of the model is significant at $5 \%$ confidence level $(\mathrm{Sig}<0.000)$. This shows that the model was significant. The $\mathrm{F}$ critical value is 2.510 while the $F$ calculated statistic $\left(F_{4,66}\right)$ is 28.706 . The findings indicate that the $F$ calculated statistic value is greater than $\mathrm{F}$ critical value $(28.706>2.510)$ indicating that the model was significant. This shows that the model was significantly fit to be used in predicting the effects of the independent variables on CounterTerrorism Capability.

The study also used regression coefficients to examine the connection between the variables of the study. The model coefficients are presented in Table 13.

Table 13. Model Coefficients

\begin{tabular}{lccccc}
\hline & \multicolumn{2}{c}{ Unstandardized Coefficients } & \multicolumn{3}{c}{ Standardized Coefficients } \\
\hline & B & Std. Error & Beta & t & Sig. \\
(Constant) & 2.576 & 0.676 & & 3.808 & 0.000 \\
Programme Content & 0.569 & 0.096 & 0.443 & 5.916 & 0.000 \\
Programme Delivery Methods & 0.413 & 0.061 & 0.512 & 6.819 & 0.000 \\
\hline
\end{tabular}
Methods

Counter Terrorism Capability $=2.576+0.569$ Programme Content +0.413 Programme Delivery

The summary of the findings in table 13 above indicate that Programme content have a strong positive and significant effect on police Counter-Terrorism Capability, $(\beta=0.569$, Significance level of 0.05). This implies that a unit increase in the various aspects of training Programme content such as the use of 
training content that equips police with terror detection skills, prevention skills, response skills, terrorrelated investigative skills and paramilitary skills leads to 0.569 unit effect in police Counter-Terrorism Capability. The findings of the study are in agreement with those of Wolf (2013) who highlighted the presence of training weaknesses especially on officer training which are insufficient with regard with Counter-Terrorism and cybercrime.

Additionally, the findings of the study revealed that training Programme delivery methods has a positive and significant association with police Counter-Terrorism Capability $(\beta=0.413$, Sig< 0.05 ). This means that a unit change in training Programme delivery methods such as the condition of the training environment, number of trainings, the frequency of trainings, the length of trainings and the level of the trainers' competence leads to a 0.413 unit change in police Counter-Terrorism Capability. The findings of the study are consistent those of McCay (2011) who indicated that there is a disparity connecting CounterTerrorism with police ideal instructional method and the concrete process applied in the college.

\section{Discussions}

The findings revealed that a majority of the respondents agreed that training Programme influences police Counter-Terrorism Capability in Kenya. Moreover, the findings showed that majority of the respondents agreed that the training Programme delivery methods in fences police Counter-Terrorism Capability in Kenya. The findings of the inferential analysis showed that training Programme content have a positive and significant relationship with the police Counter-Terrorism Capability in Kenya implying that an improvement in the use of training Programme content that equips police with terror detection skills, prevention skills, response skills, terror-related investigative skills and paramilitary skills leads to a positive and significant improvement in police Counter-Terrorism Capability.

The findings also indicated that training programme delivery methods had a positive and significant association with police Counter-Terrorism Capability in Kenya implying that an improvement in the training Programme delivery methods such as the condition of the training environment, number of trainings, the frequency of trainings, the length of trainings and the level of the trainers' competence positively and significantly influences police Counter-Terrorism Capability. The findings are consistent with the findings of Pelfrey (2010) which revealed that $37 \%$ of the agencies had participated in scenario training. The study concluded that law enforcement agencies were not the only agencies that conducted scenario training.

The findings of the informant interviews regarding whether police training Programme adequately equip police officers with Counter-Terrorism detection skills showed that police receive skills such as 'Handle Counter Terrorism Activities'. Moreover, the informants indicated that police recruits and those under specialized training receive 'Recognise Terrorist Threats training'. This enables the police to be able to spot or detect terrorist acts and other Terrorism related activities. According to the informants, police recruits are equipped with terror response skills such as judgement calls during stress.

On whether the police training curriculum offers practical Counter-Terrorism skills to the recruits or in-service officers, the informant revealed that police receive the most adequate and practical training in terms of knowledge, skills for combating Terrorism incidences. Moreover, the informants indicated that latest technological equipment in terms of machinery and sophisticated hardware. Further, the informants revealed that the nature of the Counter-Terrorism training offered to the recruits vary across the police formation.

\section{Conclusions}

Based on the findings, the study concluded that training Programme content have a positive and significant influence on police Counter-Terrorism Capability in Kenya. The use of training Programme content so as to equip the police with terror detection skills, prevention skills, response skills, terror-related investigative skills and paramilitary skills positively and significantly influences the Counter-Terrorism Capability of police in Kenya. Moreover, the study established that training Programme delivery methods has a positive and significant effect on police Counter-Terrorism Capability. The study established that a change in training Programme delivery methods such as the condition of the training environment, number of trainings, the frequency of trainings, the length of trainings and the level of the trainers' competence can lead a significant effect in police Counter-Terrorism Capability in Kenya. 


\section{References}

1. Abraham, A., \& Collins, D. (2011).Taking the next step: Ways forward for coaching science. Quest, 63(4), 366-384.

2. Baker, T.E., (2011). Effective police leadership - moving beyond Capability, 3-ed edition, Looseleaf Law Publications, New York.

3. Chappel A. T. (2008). Police academy training: comparing across curricula. Policing: An International Journal of Police Strategies \& amp; Capability, Vol. 31, No. 1 pp. 36-56.

4. Chappell, A. T., \& Lanza-Kaduce, L. (2010). Police academy socialization: Understanding the lessons learned in a paramilitary-bureaucratic organization. Journal of contemporary ethnography, 39(2), 187-214.

5. Creswell, J. W., \& Plano Clark, V. L. (2011). Designing and conducting mixed methods research (2nd ed.). Los Angeles: Sage.

6. Kothari, C. R. (2014). Research Methodology: Methods and techniques. New Age International.

7. Mbuba J., (2017). Policing in Eastern Africa. A focus on the National Police Service in Kenya. LawAfrica.

8. Mbuba, J. (2014). An Imagery Presentation of the Kenyan Law Enforcement Process: Police Training, Crime Control, and Remand Cells.

9. McCay S., (2011). Cops, computers and the curriculum. International Journal of Police Science \& Capability, 8(2), 153-158.

10. Mogire, E., \& Mkutu Agade, K. (2011).Counter-Terrorism in Kenya. Journal of Contemporary African Studies, 29(4), 473-491.

11. Mugenda, O. Mugenda (2012). Research Methods Dictionary.

12. Obisi, C. (2011). Employee training and development in Nigerian organizations: Some observations and agenda for research. Australian Journal of Business and Capability Research, 1(9), 82.

13. Oguzhan Ç. (2012). The Effect of Conflict Theory Based Decision-Making Skill Training PsychoEducational Group Experience on Decision Making Styles of Adolescents. Educational Sciences: Theory \& Practice. Vol. 12(2) 669-676

14. Palmer, M. L., (2014). Training in community policing: A suggested curriculum. Policing: An International Journal of Police Strategies \& Capability, 23(1), 8-21.

15. Pelfrey (2010). Homeland security education: A way forward.

16. Ritchie, J., Lewis, J., Nicholls, C. M., \& Ormston, R. (Eds.). (2013). Qualitative research practice: A guide for social science students and researchers. Sage.

17. Sandler, T. (2015). Terrorism and Counter-Terrorism: an overview. Oxford Economic Papers, 67(1), 1-20.

18. Sedevic, M. T. (2012). An evaluation of the Emergency Response Week curriculum. Policing: An International Journal of Police Strategies \& Capability, 35(3), 438-457.

19. Udrea, C., (2014). Pedagogical strategies for continuous training in the police system. ProcediaSocial and Behavioral Sciences, 142, 597-602.

20. Werth, E. P. (2011). Scenario training in police academies: Developing students' higher-level thinking skills. Police Practice and Research, 12(4), 325-340.

21. Wolf, J. W. (2013). The training curriculum at Pennsylvania municipal police academies: Perceptions of effective training. Indiana University of Pennsylvania. 